\title{
BEST PRACTICE AS ACTUAL AND RELATIVE BENCHMARK TO INEFFICIENT UNITS: MULTISET DEA ANALYSIS
}

Dubravka R. Vuković

"Srbija kargo" JSC, Traffic and Transport Department, Belgrade, Republic of Serbia, e-mail: dub.vukovic@gmail.com, ORCID iD: 10 http://orcid.org/0000-0003-1341-2568

DOI: 10.5937/vojtehg66-16155; https://doi.org/10.5937/vojtehg66-16155

FIELD: Mathematics, Logistics, Traffic Engineering

ARTICLE TYPE: Original Scientific Paper ARTICLE LANGUAGE: English

\section{Summary:}

The direction in research of the efficiency of decision-making units in this paper is an efficient $\rightarrow$ multi-inefficient $\rightarrow$ multi-efficient unit. So, the general purpose of this paper is twofold: (1) identification of «hidden» inefficient units within a multi-set, among efficient units of the basic set, and (2) achieving the efficiency in such identified inefficient units. This indicates (warns of!) a negative efficient $\rightarrow$ inefficient process, so as to provide a timely response and thereby prevent multi-inefficiency. The specific goal is to assess the efficiency of the Serbian railway passenger stations, first within the basic set of the Passenger Transport Section Belgrade, then in the multi-set of the Passenger Transport Sections, and finally in the superset, the Passenger Transport Sector. This is achieved by means of the multi-set DEA (Data Envelopment Analysis) method, which is a system for: (i) relative efficiency assessment, in the first iteration, through the basic set analysis, and (ii) decrease in efficiency of potentially inefficient units, in subsequent iterations, through the multi-set analysis. The result is that the efficient stations Požarevac and Pančevo Bridge are at the initial level, and the (newly) efficient Požarevac, Novi Sad and Inđija at the final level. The best practice station remains the Požarevac Station, which is multi-efficient, and therefore the role model to inefficient stations. The conclusion is drawn that the solution resulting from the multi-set DEA analysis is more realistic, and less relative, because it applies to a wider analysed set of decision-making units, i.e., a larger coverage when considering the issue. This is important for fitting into the new era of growing globalization, and therefore our recommendation is the integral multi-set, as opposed to the individual single set approach.

Key words: Efficiency, Data Envelopment Analysis, Multi-Set Analysis, Railway Stations. 


\section{Introduction}

A number of same-type organisational units within a single organisation jointly accomplish the objective of the organisation, thereby contributing to a higher or lesser extent. In order for the organisation to be successful, it is necessary for all of its units to be successful. Success is a multidimensional concept, with efficiency being one of its dimensions.

Efficiency is a feature of someone or somebody (people, institutions, organisations, companies, processes and other) to produce maximum output (products, services) using minimum input (resources, activities). Expressed in the simplest mathematical terms, it is the ratio of an output and an input. From a more complex mathematical point of view, it is a ratio between the weighted sum of multiple outputs and weighted sum of multiple inputs. For this purpose, the Data Envelopment Analysis, (DEA) was created in 1978 by Charnes, Cooper and Rhodes as a method of calculating the efficiency of the so-called Decision Making Units, abbreviated DMU), (Charnes et al, 1978).

The idea of this paper is to decrease the relativity and to increase the reality of the best practice through the iterative procedure "efficient $\rightarrow$ inefficient" (efficient unit in the basic set, inefficient in the multiset). Thus, success is a relative and changeable category and requires caution and constant reconsideration. With the view to the future, the goal of this paper is an early discovery of potentially inefficient so-called "hidden" units, and their respective timely redirecting.

Among numerous examples of best practices of similar companies, both local and foreign, the most suitable example is a so-called personal example, and that is the example of the same analysed set of measuring units. This is because all the units of the same company as means of their teamwork, under the same conditions, contribute to the accomplishment of a single goal. Logical conclusion is the requirement for all the units to proportionally contribute to this objective, whereby inefficient units imitate the efficient ones. And when those efficient units, acting as models for the inefficient ones, are "among us" or "ours", we believe that the efficiency can really be achieved.

On the one hand, the Sensitivity analysis of a single same set of decision making units, but applying different input/output data and opposite DEA models, results in the same efficiency (Vuković, 2016). On the other hand, the stated Multiset DEA analysis of the same data of decision-making units in a number of different, ever bigger sets, results in smaller or equal efficiency, so some efficient units become inefficient. By 
application of the post DEA sensitivity analysis, newly efficient units become efficient in a wider set, a so-called multiset. Thus the research direction is efficient $\rightarrow$ multiinefficient $\rightarrow$ multiefficient units. From this point of view, the goal is two steps ahead: recognition of potentially inefficient units and achieving efficiency in a wider set. Multiset efficiency is more weighted than the monoset, as is it obatined by further decrease of input and/or increase of output, thereby improving the operation of units, which defines the contribution of our paper.

The following chapters include the overview of references, the short descriptions of the DEA method and the Multiset DEA analysis, as well as a numerical example, while the conclusion has been provided based on the stated information.

\section{Overview of references}

Having reviewed the newly published worldwide and local literature, we herewith provide the following observations:

1. Efficiency is monoset-oriented, where each decision-making unit is analysed in the same set. Examples of such sets include: 208 clinical commissions in England (Takundwa et al, 2017), 42 bus routes in Brisbane, Australia (Tran et al, 2017), and 55 universities in the state of Mexico (Sagarra et al, 2017). While in these works each unit is analysed in the same set, we here observe a unit in a wider scale, as an element of every bigger set. It is thus possible to compare the efficiency results obtained through multisets and to provide a more realistic assessment of efficiency.

2. The problem of the multiset prediction is not well known in the literature. According to certain authors, the problem is solved by consecutive decision-making, where a new multiset function of loss is proposed as a parameter of predictive policy (Welleck et al, 2017). According to others, the multiset approach is used to predict the average daily temperature, as shown by the Taipei example in Taiwan (Vamitha \& Rajaram, 2015). In our paper, the Multiset DEA analysis of units is used for predicting inefficient results, which meant increasing the set of decision-making units by adding a new set. In this way, potentially inefficient units are more accurately predicted, which is helpful in solving the problems of multiset prediction.

3. The multiset theory differentiates between conventional and fuzzy logic. Conventional logic defines whether an element belongs to a set by "yes or no", whereas fuzzy logic does so by "more or less" (Pamučar et al, 2016). The Multiset DEA analysis is a connection between the 
multiset theory and the DEA method. The stated analysis defines the simultaneous belonging of elements to a larger number of sets by "yes", with multiset efficient units. In addition, it also uses "yes", with multiset inefficient units. Realistically, a multiset is a family of a set of efficient and a set of inefficient units. Units "more or less" belong to a multiset, where units closer by efficiency belong to a multiset "more", and with the deviation "less".

4. Efficiency is dealt with without burdening the external society, but individually instead, within the scope of internal potential. The example of this case are premises used by institutions, command departments and units of the Serbian Army, where the application of thermal isolation is proposed to solve the problem of energy efficiency (Živković \& Banjac, 2016). By applying the stated idea of using internal potential, we are solving a complex problem of efficiency of railway stations, with an additional idea of using its diverse potential, not just material but also organisational, and thereby achieving certain savings.

5. Organisational efficiency is impossible without the evaluation of the work of employees, which requires management so that it could be managed (maximised) in this way (Lukovac et al, 2014). Measurement of work at different levels by a multiset approach is a higher stage of comparison.

\section{Core principles of DEA (Data Envelopment Analysis)}

DEA is a method of mathematical programming for the calculation of efficiency and it is used, from a wider perspective, in economy, and more precisely, in different kinds of economics, depending on the type of decision making units. This is supported by numerous and diverse examples from the world and local literature, covering different types of Economics:

- Health Economics, where the effectiveness of health organizations is being decided upon (an example of this type of units is the public health system and the medical protection system of the OECD countries (Ozcan \& Khushalani, 2017);

- Traffic Economics, where the effectiveness of transport organizations is being decided upon (examples are the Brazilian intermodal terminals), (Peixoto et al, 2017);

- Sports Economics, where the decision on the efficiency of sports organizations is being decided upon (for example, the football team of Serbia), (Petrović Đorđević, 2015); 
- Tourism Economics, involving decision making on the efficiency of tourism organizations (e.g. ecotourism parks), (Lin et al, 2017);

- Business Economics, where the effectiveness of business organizations is being decided upon (for example, Taiwanese insurance companies), (Chen \& Zhu, 2017);

- Economics of Education, where the decision making on the effectiveness of educational organizations is being decided upon (examples are Chinese educational organizations, from pre-school to higher education), (Si \& Qiao, 2017);

The algorithm of the selection process with the DEA method application includes five steps, as presented in Figure 1.

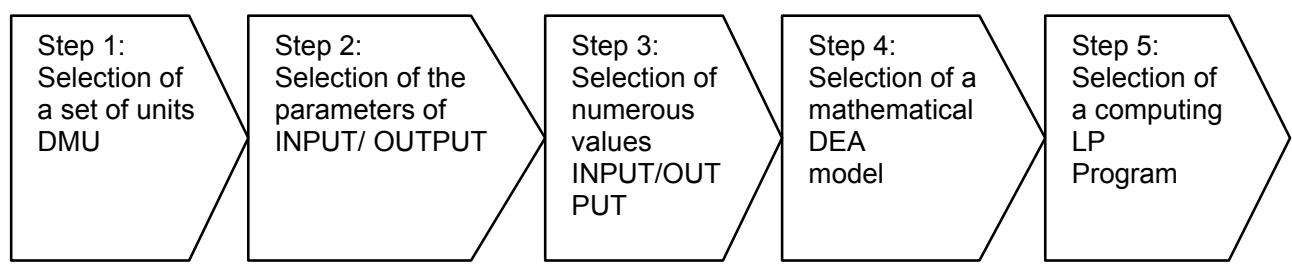

Figure1 - DEA method application algorithm

Рисунок 1 - Алгоритм применения АОД метода

Слика 1 - Алгоритам примене ДЕА методе

According to Figure 1, each example of a particular DEA method is characterised by the concrete: decision making units (DMU), input-output parameters (INPT/OUPT), numerous values of input and output, mathematical DEA model (Charnes et al, 1978), (Banker et al, 1984), (Yang et al, 2000), and a computer program (MS Excel Solver, LINDO, LINGO and other) for solving linear programming (LP) tasks, whose result is the efficiency value for each decision making unit.

By the application of the DEA method, decision making units are divided into two groups: efficient $(\mathrm{Eff}=1)$ and inefficient $(0<\mathrm{Eff}<1)$, while according to their numerical values they have a number of comparison stages, so it is possible to establish a ranking (complete or incomplete) of decision making units. Efficient units obtained based on the actual data are realistically best practice units, but they are also a substandard of efficiency as they are valid only for a concrete example (case study). Opposite to this is a generally applied standard which does not exist in this case, as there is no absolute efficiency. 


\section{Multiset DEA analysis}

The Multiset DEA analysis is based on the fact that sets are not of exact size, but can be changed depending on the number of elements. Hence, the limit i.e. the final size of a set remains unknown. And it is exactly the issue of the limit of the set, being the analysis framework, which is significant for the efficiency value. The above analysis contains the principle that all the units outside the basic set break the ranking of the units of the basic set, by the value of efficiency, by analysing them in sets, which are at different (organizational, hierarchical) levels. A complete set is not known, so it is unknown which is the highest possible efficiency i.e. only experiential efficiency is known.

Similar to Savić's idea (Savić, 2017) that the algorithm should be applied several times, whereby a single input or output is added in each iteration, the idea of our paper is to add more decision-making units to each iteration, i.e. a new set of DMUs which represent a single organizational unit. However, while in the previously stated reference "turning" points among the iterations referred to the inputs/outputs (qualitative characteristics of the DMU), the "turning" points here are the sets of DMUs (quantitative characteristics). Changing qualitative features or changes of content are a feature of a systemic approach, while the change in quantitative characteristics or changes in the size of a set of features, discussed herewith, is a multi-set approach.

The multiset DEA analysis estimates the efficiency of the decisionmaking unit, where a unit is an element in each iteration of a new wider set. The first DEA model which we will use, from which many modified models are devised, is the CCR model (Charnes et al, 1978) whose multiset mathematical formulation consists of sets of decision making units in which the goal function is maximized with the set limits, Table 1.

According to Table 1, the Multiset DEA analysis is an iterative process of maximizing the function of the objective $h_{0}$ (efficiency) under the given restrictions, in ever increasing set till the final total sum set of all $p$ basic sets (BSp).

The idea of the Multiset analysis is contrary to the idea of the post DEA Sensitivity Analysis. The Sensitivity analysis yields targeted activities (target values of inputs and outputs), which by the realization of an inefficient unit become effective. Contrary to this, the Multiset analysis is a kind of prediction that produces non-targeted (undesirable) inefficient units, by making some efficient units inefficient in the multiset, Figure 2. 
Table 1 - Multi-Set DEA Analysis Mathematical Model

Таблица 1 - Математическая модель Мульти-множественного АОД анализа Табела 1 - Математички модел мултискуповне ДЕА анализе

\begin{tabular}{|c|c|c|}
\hline Multi-set model & DEA model & Meaning of symbols \\
\hline $\begin{array}{l}\text { DMUj€ }\{\mathrm{OS} 1\} \vee\{\mathrm{OS} 2\} \vee \ldots\{\mathrm{OSp}\} \\
\{\mathrm{OS} 1\} \cup\{\mathrm{OS} 2\} \cup \ldots \cup\{\mathrm{OSp}\}=\{\mathrm{NS}\} \\
\mathrm{OS} 1=\{\mathrm{DMU} 1, \mathrm{DMU} 2, \ldots, \mathrm{DMUa}\} \\
\mathrm{OS} 2=\{\mathrm{DMUa}+1, \ldots, \mathrm{DMUb}\} \\
\ldots \\
\mathrm{OSp}=\{\mathrm{DMUd}+1, \ldots, \mathrm{DMUg}\}\end{array}$ & $\begin{array}{l}\max h_{0}=\frac{\sum_{r=1} u_{r} y_{r 0}}{\sum_{i=1}^{m} v_{i} x_{i 0}} \\
\frac{\sum_{r=1}^{s} u_{r} y_{r j}}{\sum_{i=1}^{m} v_{i} x_{i j}} \leq 1 \\
j=1, \ldots n \\
u_{r} \geq 0, r=1, \ldots, s \\
v_{i} \geq 0, i=1, \ldots, m\end{array}$ & $\begin{array}{l}h_{0} \text {-efficiency of DMU } \\
\text { for which is calculated } \\
y_{r j}-\text { output of } j \text { DMU } \\
x_{i j}-\text { input of } j \text { DMU } \\
n-\text { number of DMU } \\
m-\text { number of input } \\
s-\text { number of ourput } \\
u_{r}-\text { weighted } \\
\text { coefficient of } r \text { output } \\
v_{i}-\text { weighted } \\
\text { coefficient of } i \text { input } \\
p-\text { no. of OS } \\
a, b, c \ldots, ., d, \ldots, g-\text { no. of } \\
\text { elements of BS }\end{array}$ \\
\hline
\end{tabular}

Inefficient Multiinefficient DMU

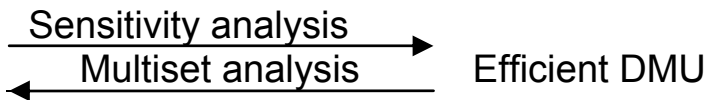

Figure 2 - Two-way process of efficiency change

Рисунок 2 - Двунаправленный процесс изменения эфрфективности Слика 2 - Двосмерни процес промене ефрикасности

According to Ljubisav Rakić: "The position of science in the century which has begun is to change the methodology. Instead of studying why something happened, we should move in the direction of predicting and studying of what could happen." (Rakić, 2017)

The essence of the Sensitivity analysis is as follows: (1) improving the efficiency of decision making units, and (2) aiming at proportionally equal contribution of all units of a set to the common goal of the company. The essence of opposite, multiset approach is viewing the units in a wider context.

The philosophy of the multiset approach may be explained by a modern theory included in the quotation of Stuart Diamond: "Each ceiling is a new floor", expressed in such a way to say that we could always get more (but not everything), which is also the name of his book (Diamond, 2015 , p.36). Applied to the topic of our paper, provided efficiency is the 
ability to maximise the results with the least possible investment - it means that by widening the analysed set by inclusion of new units we can get the efficiency of higher weight (the efficiency of the units of the basic set decreases or remains the same with multiset efficient units).

Within the context of the multiset DEA analysis of efficiency, this means that the current efficiency is disturbed by inclusion of new units and may always be overcome by new units included in the set of the analysed units, and thus new efficient units are being formed.

If, according to Marjanović (Vešović et al, 2007), the basic goals of the company are survival, facilitation of survival (efficiency of operation) and progress, then within the context of the multiset approach:

1. The current state of the set indicates: the survival (the organisation is operating with both efficient and inefficient units).

2. Targeted state of the set obtained by the Sensitivity analysis marks: Facilitating survival (as a result of targeted activities, all inefficient units become efficient).

3. Higher targeted state of the set obtained by Multiset DEA analysis marks: Progress (as the result of increase in the size of the set, the criterion for reaching efficiency has become more demanding, as the former efficient units with the same values of input-output parameters become inefficient). Therefore, the efficiency in a larger set is more weighted than the efficiency in smaller set.

Real evaluation of the efficiency for the previous period is performed by solving the preferred DEA model, or Ex-post evaluation of efficiency (backwards evaluation) for each of the analysed units of decision making. The sensitivity analysis provides the desired estimation for the future period or Ex-ante evaluation of efficiency (forward evaluation), only for inefficient units of decision making (efficient decision making units already have the desired efficiency for the unit).

\section{Case study: Railway stations of IŽS Company}

The Multiset DEA analysis is a universal system for the evaluation of efficiency of entities and their arrangement according to a given efficiency, within diverse numeric examples. However, with each individual application, it is necessary for entities to be of the same kind, as it is widely known and logical that comparison makes sense only in such circumstances. A realistic example of such entities are Serbian railway passenger stations, which are subject of our research with the aim of illustrating the stated analysis. But, why railway, why railway stations and why at this moment? 
Railway is a type of transport for passengers and goods, used for civil purposes, for transporting people and equipment, and also for military purposes. Theoretically, its advantages are numerous and important in terms of transport power, traffic safety, spatial acquisition, consumption of energy, emissions of harmful substances, noise and other, which make it competitive. Railway stations are important infrastructure facilities in the transport process; apart from this, they are numerous, and financially valuable. They are also important to us as a place of departures and arrivals, loadings and unloadings. In the new era of business, according to the principle of a liberal, supranational market, it is compulsory for companies to be efficient and trending for continuous improvement. Hence, it is necessary to continuously monitor and comply with complex and expensive interoperability flows. To this purpose, a case study: Serbian Railway Passenger Stations.

On the one hand (theoretically), Serbian railway passenger stations are decision making units (DMU) within the DEA method, and on the other hand (practically), railway stations (RS) are infrastructural facilities within the Infrastruktura železnica Srbije Company (IŽS), Table 2. Six-set DEA analysis following the enlargement of a single-set example (Vuković, 2016).

Table 2 - Example in practice of the Serbian railways Таблица 2 - Пример из практики сербских железных дорог Табела 2 - Пример из праксе српских железница

\begin{tabular}{|l|l|l|l|l|l|}
\hline \multicolumn{2}{|l|}{ DEA method } & \multicolumn{3}{|l|}{ IŽS company } \\
\hline \multicolumn{4}{|l|}{ DMU as element of DEA } & \multicolumn{2}{|l|}{ RS as element of IŽS } \\
\hline Superset & Set & Subset & Railway station & Section & Sector \\
\hline LS & BS1 & DMU1 & Belgrade & 1.Passanger & Passenger \\
Transport \\
Section \\
Belgrade \\
(including \\
Transport \\
Sector \\
\end{tabular}




\begin{tabular}{|c|c|c|c|c|c|}
\hline \multicolumn{3}{|c|}{ DEA method } & \multicolumn{3}{|l|}{ IŽS company } \\
\hline \multicolumn{3}{|c|}{ DMU as element of DEA } & \multicolumn{3}{|c|}{ RS as element of IŽS } \\
\hline Superset & Set & Subset & Railway station & Section & Sector \\
\hline & & DMU12 & Požarevac & & \\
\hline & & DMU13 & Smederevo & & \\
\hline & & DMU14 & Mala Krsna & & \\
\hline & & DMU15 & Vranovo & & \\
\hline & & DMU16 & Radinac & & \\
\hline & \multirow{12}{*}{$\begin{array}{l}\text { BS2 } \\
12 \text { DMU }\end{array}$} & DMU17 & Lapovo & \multirow{12}{*}{$\begin{array}{l}2 . \\
\text { Passanger } \\
\text { Transport } \\
\text { Section } \\
\text { Lapovo } \\
\text { (including } \\
\text { OU Kraljevo) }\end{array}$} & \\
\hline & & DMU18 & Jagodina & & \\
\hline & & DMU19 & Stalać & & \\
\hline & & DMU20 & Paraćin & & \\
\hline & & DMU21 & Velika Plana & & \\
\hline & & DMU22 & Ćuprija & & \\
\hline & & DMU23 & Ćićevac & & \\
\hline & & DMU24 & Palanka & & \\
\hline & & DMU25 & Kraljevo & & \\
\hline & & DMU26 & Kragujevac & & \\
\hline & & DMU27 & Raška & & \\
\hline & & DMU28 & Čačak & & \\
\hline & \multirow{12}{*}{$\begin{array}{l}\text { BS3 } \\
12 \text { DMU }\end{array}$} & DMU29 & Niš & \multirow{12}{*}{$\begin{array}{l}3 . \\
\text { Passenger } \\
\text { Transport } \\
\text { Section Niš } \\
\text { (with OU } \\
\text { Zaječar) }\end{array}$} & \\
\hline & & DMU30 & Leskovac & & \\
\hline & & DMU31 & Pirot & & \\
\hline & & DMU32 & Dimitrovgrad & & \\
\hline & & DMU33 & Vranje & & \\
\hline & & DMU34 & Palilulska Rampa & & \\
\hline & & DMU35 & Crveni Krst & & \\
\hline & & DMU36 & Aleksinac & & \\
\hline & & DMU37 & Zaječar & & \\
\hline & & DMU38 & Knjaževac & & \\
\hline & & DMU39 & Negotin & & \\
\hline & & DMU40 & Bor & & \\
\hline & \multirow{8}{*}{$\begin{array}{l}\text { BS4 } \\
18 \mathrm{DMU}\end{array}$} & DMU41 & Novi Sad & \multirow{8}{*}{$\begin{array}{l}4 . \\
\text { Passenger } \\
\text { Transport } \\
\text { Section Novi } \\
\text { Sad } \\
\text { (including } \\
\text { OU Ruma } \\
\text { and OU } \\
\text { Zrenjanin) }\end{array}$} & \\
\hline & & DMU42 & Beška & & \\
\hline & & DMU43 & Čortanovci & & \\
\hline & & DMU44 & Sremski Karlovci & & \\
\hline & & DMU45 & Vrbas & & \\
\hline & & DMU46 & Odžaci & & \\
\hline & & DMU47 & Zmajevo & & \\
\hline & & DMU48 & Petrovaradin & & \\
\hline
\end{tabular}




\begin{tabular}{|c|c|c|c|c|c|}
\hline \multicolumn{3}{|c|}{ DEA method } & \multicolumn{3}{|l|}{ IŽS company } \\
\hline \multicolumn{3}{|c|}{ DMU as element of DEA } & \multicolumn{3}{|c|}{ RS as element of IŽS } \\
\hline Superset & Set & Subset & Railway station & Section & Sector \\
\hline & & DMU49 & Ruma & & \\
\hline & & DMU50 & Šabac & & \\
\hline & & DMU51 & Šid & & \\
\hline & & DMU52 & Inđija & & \\
\hline & & DMU53 & Stara Pazova & & \\
\hline & & DMU54 & Nova Pazova & & \\
\hline & & DMU55 & Sremska Mitrovica & & \\
\hline & & DMU56 & Zrenjanin & & \\
\hline & & DMU57 & Zrenjanin Factory & & \\
\hline & & DMU58 & Kikinda & & \\
\hline & \multirow{8}{*}{$\begin{array}{l}\text { BS5 } \\
8 \mathrm{DMU}\end{array}$} & DMU59 & Subotica & \multirow{8}{*}{$\begin{array}{l}5 . \\
\text { Passenger } \\
\text { Transport } \\
\text { Section } \\
\text { Subotica }\end{array}$} & \\
\hline & & DMU60 & Sombor & & \\
\hline & & DMU61 & Sonta & & \\
\hline & & DMU62 & Prigrevica & & \\
\hline & & DMU63 & Senta & & \\
\hline & & DMU64 & Bogojevo & & \\
\hline & & DMU65 & Žednik & & \\
\hline & & DMU66 & Horgoš & & \\
\hline & \multirow{7}{*}{$\begin{array}{l}\text { BS6 } \\
7 \text { DMU }\end{array}$} & DMU67 & Užice & \multirow{7}{*}{$\begin{array}{l}6 . \\
\text { Passenger } \\
\text { Transport } \\
\text { Section } \\
\text { Užice }\end{array}$} & \\
\hline & & DMU68 & Požega & & \\
\hline & & DMU69 & Priboj & & \\
\hline & & DMU70 & Valjevo & & \\
\hline & & DMU71 & Prijepolje & & \\
\hline & & DMU72 & Lazarevac & & \\
\hline & & DMU73 & Lajkovac & & \\
\hline
\end{tabular}

Based on Table 2, there are 73 railroad stations within the network of Serbian Railways. They are organized in two levels: (1) Passenger Transport Sector, at a higher organizational level; and (2) Passenger Transport Section, at a lower organizational level. The sector includes six sections, four of which have organizational units (OU), as a lower organizational level. The seats of the Sections (Belgrade, Lapovo, Niš, Novi Sad and Subotica) are important railway hubs, where more lines are obtained, with more intensive traffic volumes, and are commercially significant places. By the very nature of their operation, the mutual cooperation of the Sections is very important because they are connected: (1) physically, by railroad tracks; (2) organizationally, by 
traffic connections (both railways and connections are usually administered by two or more Sections). Hence, it is important that they are all efficient, in order to maintain the continuity of the technological process of work. Namely, the inefficiency of one of them jeopardizes the efficiency of any other.

If we select the following input/output parameters as follows:

- The man: "basic factor of each production, including the production of transport or post office service. It simultaneously appears as its organiser, manager and executor." (Vešović et al, 2007. p.186),

- Produced service: "Standard measure of the volume of the whole economy is the gross domestic product (GDP), which represents the value of all gods and services produced in an economy within a year." (Stiglitz, 2008, p.38),

- Wok performance: the purpose, and therefore the point of performing the works, is to gain profit,

then the following parameters are selected in our case according to the given logic: (i) number of cashiers (entry 1), (ii) number of dispatched trains (entry 2), (iii) number of dispatched passengers (exit). The sources of the concrete data for our case include:

- Job classification within the company in 2010: number of cashiers, (Železnice Srbije, 2010);

- Timetable 2013/2014: number of trains, (Železnice Srbije, 2013);

- Statistics of Serbian Railways 2013: number of passengers, (Železnice Srbije, 2014).

The option A of the multi-set DEA analysis analyses units in each basic set individually (left side of Table 3 ) and units in the total sum superset (right side of Table 3). The application of the CCR DEA model from Table 1 results in the values of efficiency of decision making units evaluated by MS Excel Solver to six decimal numbers, Table 3.

According to Table 3, the application of the Section analysis resulted in the total of 12 efficient units, which are the best practice units, whereas the Sector analysis resulted in only three efficient units: Požarevac, Novi Sad and Indjija. The remaining nine, DMU7,18,24,25,30,37,59,66 and 67, so called "hidden" inefficient units, have been discovered by the analysis of the superset of Sectors, where they become inefficient.

This indicates the sensitivity of the DEA method to a change in a set size. A quotation of Andersen and Petersen states (Andersen \& Petersen, 1993, p.1261): A weakness of DEA is that a considerable number of observations typically is characterized as efficient, unless the sum of the number of inputs and outputs is small relative to the number of observations. 
Table 3 - Decision-making unit efficiency in the basic sets and in a superset

Таблица 3 - Эфрфективность единиц принятия решений в основном множестве и надмножестве

Табела 3 - Ефикасност јединица одлучивања у основним скуповима и надскупу

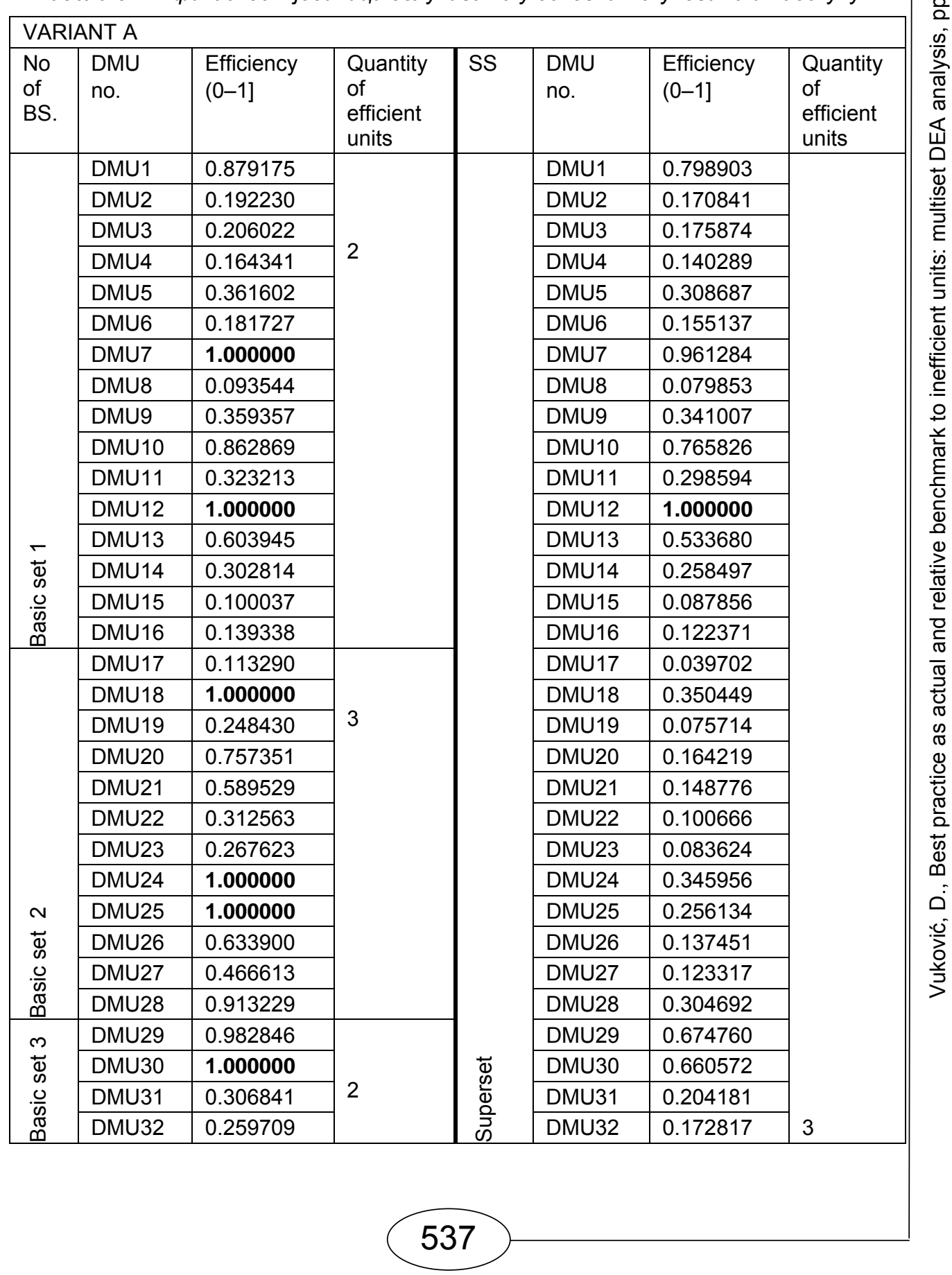




\begin{tabular}{|c|c|c|c|c|c|c|c|}
\hline \multicolumn{8}{|c|}{ VARIANT A } \\
\hline $\begin{array}{l}\text { No } \\
\text { of } \\
\text { BS. }\end{array}$ & $\begin{array}{l}\text { DMU } \\
\text { no. }\end{array}$ & \begin{tabular}{|l|} 
Efficiency \\
$(0-1]$
\end{tabular} & $\begin{array}{l}\text { Quantity } \\
\text { of } \\
\text { efficient } \\
\text { units }\end{array}$ & SS & $\begin{array}{l}\text { DMU } \\
\text { no. }\end{array}$ & $\begin{array}{l}\text { Efficiency } \\
(0-1]\end{array}$ & $\begin{array}{l}\text { Quantity } \\
\text { of } \\
\text { efficient } \\
\text { units }\end{array}$ \\
\hline \multirow{8}{*}{ 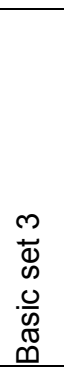 } & DMU33 & 0.439482 & & & DMU33 & 0.148063 & \\
\hline & DMU34 & 0.249361 & & & DMU34 & 0.165932 & \\
\hline & DMU35 & 0.555812 & & & DMU35 & 0.187271 & \\
\hline & DMU36 & 0.647396 & & & DMU36 & 0.367192 & \\
\hline & DMU37 & 1.000000 & & & DMU37 & 0.877614 & \\
\hline & DMU38 & 0.490002 & & & DMU38 & 0.320747 & \\
\hline & DMU39 & 0.472408 & & & DMU39 & 0.303723 & \\
\hline & DMU40 & 0.767057 & & & DMU40 & 0.468147 & \\
\hline \multirow{18}{*}{ 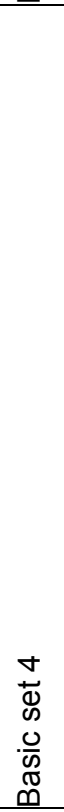 } & DMU41 & 1.000000 & \multirow{18}{*}{2} & & DMU41 & 1.000000 & \\
\hline & DMU42 & 0.488504 & & & DMU42 & 0.488504 & \\
\hline & DMU43 & 0.266385 & & & DMU43 & 0.266385 & \\
\hline & DMU44 & 0.148627 & & & DMU44 & 0.148627 & \\
\hline & DMU45 & 0.544243 & & & DMU45 & 0.544243 & \\
\hline & DMU46 & 0.126275 & & & DMU46 & 0.126275 & \\
\hline & DMU47 & 0.307956 & & & DMU47 & 0.307956 & \\
\hline & DMU48 & 0.133064 & & & DMU48 & 0.133064 & \\
\hline & DMU49 & 0.215982 & & & DMU49 & 0.215982 & \\
\hline & DMU50 & 0.327164 & & & DMU50 & 0.327164 & \\
\hline & DMU51 & 0.340419 & & & DMU51 & 0.340419 & \\
\hline & DMU52 & 1.000000 & & & DMU52 & 1.000000 & \\
\hline & DMU53 & 0.732659 & & & DMU53 & 0.732659 & \\
\hline & DMU54 & 0.522205 & & & DMU54 & 0.522205 & \\
\hline & DMU55 & 0.422567 & & & DMU55 & 0.422567 & \\
\hline & DMU56 & 0.387019 & & & DMU56 & 0.387019 & \\
\hline & DMU57 & 0.022979 & & & DMU57 & 0.022979 & \\
\hline & DMU58 & 0.041560 & & & DMU58 & 0.041560 & \\
\hline \multirow{8}{*}{ 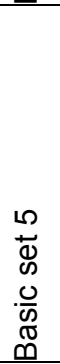 } & DMU59 & 1.000000 & \multirow{8}{*}{2} & & DMU59 & 0.477291 & \\
\hline & DMU60 & \begin{tabular}{|l|l|}
0.721202 \\
\end{tabular} & & & DMU60 & 0.321932 & \\
\hline & DMU61 & 0.558896 & & & DMU61 & 0.178442 & \\
\hline & DMU62 & 0.584930 & & & DMU62 & 0.186759 & \\
\hline & DMU63 & 0.166865 & & & DMU63 & 0.074945 & \\
\hline & DMU64 & 0.063039 & & & DMU64 & 0.020127 & \\
\hline & DMU65 & 0.873175 & & & DMU65 & 0.278792 & \\
\hline & DMU66 & 1.000000 & & & DMU66 & 0.443437 & \\
\hline
\end{tabular}




\begin{tabular}{|c|c|c|c|c|c|c|c|}
\hline \multicolumn{8}{|c|}{ VARIANT A } \\
\hline $\begin{array}{l}\text { No } \\
\text { of } \\
\text { BS. }\end{array}$ & $\begin{array}{l}\text { DMU } \\
\text { no. }\end{array}$ & $\begin{array}{l}\text { Efficiency } \\
(0-1]\end{array}$ & $\begin{array}{l}\text { Quantity } \\
\text { of } \\
\text { efficient } \\
\text { units }\end{array}$ & SS & $\begin{array}{l}\text { DMU } \\
\text { no. }\end{array}$ & $\begin{array}{l}\text { Efficiency } \\
(0-1]\end{array}$ & $\begin{array}{l}\text { Quantity } \\
\text { of } \\
\text { efficient } \\
\text { units }\end{array}$ \\
\hline \multirow{7}{*}{ 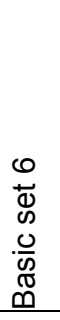 } & DMU67 & 1.000000 & \multirow{7}{*}{1} & & DMU67 & 0.774963 & \\
\hline & DMU68 & 0.602181 & & & DMU68 & 0.296396 & \\
\hline & DMU69 & 0.691438 & & & DMU69 & 0.470662 & \\
\hline & DMU70 & 0.955143 & & & DMU70 & 0.508139 & \\
\hline & DMU71 & 0.661295 & & & DMU71 & 0.419728 & \\
\hline & DMU72 & 0.521605 & & & DMU72 & 0.191992 & \\
\hline & DMU73 & 0.135552 & & & DMU73 & 0.049899 & \\
\hline \multicolumn{3}{|c|}{ efficient units } & 12 & \multicolumn{3}{|c|}{ Totally efficient units } & 3 \\
\hline
\end{tabular}

Figure 3 - Best practice units in the Section (12 units) and the Sector (3 units) Рисунок 3 - Единицы передовой практики в Секции (12 единиц) и Секторе (3 единицы)

Слика 3 - Јединице најбоље праксе у секцији (12 јединица) и сектору (3 јединице)

The ratio between the Sector efficiency $(E f f \leq 1)$ and the Section efficiency $(E f f=1)$, for 12 efficient units in the Section, may be seen from the graph presented in Figure 3. The highest span is of DMU25 which is on the verge of efficiency $(0.256134 / 1)$, with the achieved $25.6 \%$ of the goal. The lowest span is with the DMU7, which is firmly efficient $(0.961284 / 1)$, with the achieved $96.1 \%$ of the target. 
For the variant $B$ of the multiset DEA analysis, through the iterative procedure, the number of DMUs gradually increases by adding the units of the following basic unit to Basic set 1, up to the superset size, Table 4.

Table 4 - Efficiency of decision-making units in BS1 and aggregate sets Таблица 4 - Эфрфективность единиц принятия решения в ОМ1 и суммарных множествах

Табела 4 - Ефрикасност јединица одлучивања у ОС1 и збирним скуповима

VARIANT B DMU $\quad$ Efficiency (16DMU) 3

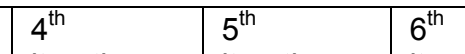
\begin{tabular}{l|l|l} 
iteration & iteration & iteration
\end{tabular} (58DMU) (66DMU) (73DMU)

\begin{tabular}{|l|l|l}
0.798903 & 0.798903 & 0.798903 \\
\hline
\end{tabular}

\begin{tabular}{|l|l|l|l|l|l|l|}
\hline DMU2 & 0.192229 & 0.192229 & 0.192229 & 0.170841 & 0.170841 & 0.170841
\end{tabular}

\begin{tabular}{|l|l|l|l|l|l|l|}
\hline DMU3 & 0.206021 & 0.206021 & 0.206021 & 0.175874 & 0.175874 & 0.175874 \\
\hline
\end{tabular}

\begin{tabular}{|l|l|l|l|l|l|l|}
\hline DMU4 & 0.164340 & 0.164340 & 0.164340 & 0.140289 & 0.140289 & 0.140289 \\
\hline
\end{tabular}

\begin{tabular}{|l|l|l|l|l|l|l|}
\hline DMU5 & 0.361602 & 0.361602 & 0.361602 & 0.308687 & 0.308687 & 0.308687 \\
\hline
\end{tabular}

\begin{tabular}{|l|l|l|l|l|l|l|}
\hline DMU6 & 0.181726 & 0.181726 & 0.181726 & 0.155137 & 0.155137 & 0.155137 \\
\hline
\end{tabular}

\begin{tabular}{|l|l|l|l|l|l|l|}
\hline DMU7 & 1.000000 & 1.000000 & 1.000000 & 0.961284 & 0.961284 & 0.961284 \\
\hline
\end{tabular}

\begin{tabular}{|l|l|l|l|l|l|l|}
\hline DMU8 & 0.093543 & 0.093543 & 0.093543 & 0.079853 & 0.079853 & 0.079853 \\
\hline
\end{tabular}

\begin{tabular}{|l|l|l|l|l|l|l|}
\hline DMU9 & 0.359357 & 0.359357 & 0.359357 & 0.341007 & 0.341007 & 0.341007 \\
\hline
\end{tabular}

\begin{tabular}{|l|l|l|l|l|l|l|}
\hline DMU10 & 0.862869 & 0.862869 & 0.862869 & 0.765826 & 0.765826 & 0.765826 \\
\hline
\end{tabular}

\begin{tabular}{|l|l|l|l|l|l|l|}
\hline DMU11 & 0.323213 & 0.323213 & 0.323213 & 0.298594 & 0.298594 & 0.298594 \\
\hline
\end{tabular}

\begin{tabular}{|l|l|l|l|l|l|l|}
\hline DMU12 & $\mathbf{1 . 0 0 0 0 0 0}$ & $\mathbf{1 . 0 0 0 0 0 0}$ & $\mathbf{1 . 0 0 0 0 0 0}$ & $\mathbf{1 . 0 0 0 0 0 0}$ & $\mathbf{1 . 0 0 0 0 0 0}$ & $\mathbf{1 . 0 0 0 0 0 0}$ \\
\hline
\end{tabular}

\begin{tabular}{|l|l|l|l|l|l|l|}
\hline DMU13 & 0.603944 & 0.603944 & 0.603944 & 0.533680 & 0.533680 & 0.533680 \\
\hline
\end{tabular}

\begin{tabular}{|l|l|l|l|l|l|l|}
\hline DMU14 & 0.302814 & 0.302814 & 0.302814 & 0.258497 & 0.258497 & 0.258497 \\
\hline
\end{tabular}

\begin{tabular}{|l|l|l|l|l|l|l|}
\hline DMU15 & 0.100036 & 0.100036 & 0.100036 & 0.087856 & 0.087856 & 0.087856 \\
\hline
\end{tabular}

\begin{tabular}{|l|l|l|l|l|l|l|l|}
\hline DMU16 & 0.139337 & 0.139337 & 0.139337 & 0.122371 & 0.122371 & 0.122371 \\
\hline
\end{tabular}

\begin{tabular}{|l|l|l|l|l|l|}
\hline DMU17 & 0.044929 & 0.044929 & 0.039702 & 0.039702 & 0.039702 \\
\cline { 3 - 7 } & 0.396589 & 0.39589 & 0.350449 & 0.350449 & 0.350449 \\
\hline
\end{tabular}

DMU18

DMU19

DMU20

DMU21

DMU22

DMU23

DMU24

DMU25

DMU26

DMU27

DMU28

\begin{tabular}{|l|l|l|l|l|}
\hline 0.044929 & 0.044929 & 0.039702 & 0.039702 & 0.039702 \\
\hline 0.396589 & 0.396589 & 0.350449 & 0.350449 & 0.350449 \\
\hline 0.088672 & 0.088672 & 0.075714 & 0.075714 & 0.075714 \\
\hline 0.177537 & 0.177537 & 0.164219 & 0.164219 & 0.164219 \\
\hline 0.157789 & 0.157789 & 0.148776 & 0.148776 & 0.148776 \\
\hline 0.111534 & 0.111534 & 0.100666 & 0.100666 & 0.100666 \\
\hline 0.092086 & 0.092086 & 0.083624 & 0.083624 & 0.083624 \\
\hline 0.389268 & 0.389268 & 0.345956 & 0.345956 & 0.345956 \\
\hline 0.287488 & 0.287488 & 0.256134 & 0.256134 & 0.256134 \\
\hline 0.148598 & 0.148598 & 0.137451 & 0.137451 & 0.137451 \\
\hline 0.143906 & 0.143906 & 0.123317 & 0.123317 & 0.123317 \\
\hline 0.349139 & 0.349139 & 0.304692 & 0.304692 & 0.304692 \\
\hline
\end{tabular}




\begin{tabular}{|c|c|c|c|c|c|c|}
\hline \multicolumn{7}{|c|}{ VARIANT B } \\
\hline \multirow{2}{*}{$\begin{array}{l}\text { DMU } \\
\text { no. }\end{array}$} & \multicolumn{6}{|l|}{ Efficiency } \\
\hline & $\begin{array}{l}1^{\text {st }} \text { iteration } \\
(16 \mathrm{DMU})\end{array}$ & $\begin{array}{l}2^{\text {nd }} \\
\text { iteration } \\
\text { (28DMU) }\end{array}$ & $\begin{array}{l}3^{\text {rd }} \\
\text { iteration } \\
\text { (40DMU) }\end{array}$ & $\begin{array}{l}4^{\text {th }} \\
\text { iteration } \\
\text { (58DMU) }\end{array}$ & $\begin{array}{l}5^{\text {th }} \\
\text { iteration } \\
\text { (66DMU) }\end{array}$ & \begin{tabular}{|l|}
$6^{\text {th }}$ \\
iteration \\
(73DMU) \\
\end{tabular} \\
\hline DMU29 & & & 0.809804 & 0,674760 & 0,674760 & 0,674760 \\
\hline DMU30 & & & 0.762116 & 0,660572 & 0,660572 & 0,660572 \\
\hline DMU31 & & & 0.237283 & 0,204181 & 0,204181 & 0,204181 \\
\hline DMU32 & & & 0.200835 & 0,172817 & 0,172817 & 0,172817 \\
\hline DMU33 & & & 0.173450 & 0,148063 & 0,148063 & 0,148063 \\
\hline DMU34 & & & 0.192833 & 0,165932 & 0,165932 & 0,165932 \\
\hline DMU35 & & & 0.219377 & 0,187271 & 0,187271 & 0,187271 \\
\hline DMU36 & & & 0.408825 & 0,367192 & 0,367192 & 0,367192 \\
\hline DMU37 & & & 0.922098 & 0,877614 & 0,877614 & \begin{tabular}{|c|}
0,877614 \\
\end{tabular} \\
\hline DMU38 & & & 0.369195 & 0,320747 & 0,320747 & 0,320747 \\
\hline DMU39 & & & 0.348028 & 0.303723 & 0.303723 & 0.303723 \\
\hline DMU40 & & & 0.529783 & 0.468147 & 0.468147 & 0.468147 \\
\hline DMU41 & & & & 1.000000 & 1.000000 & \begin{tabular}{|l|}
1.000000 \\
\end{tabular} \\
\hline DMU42 & & & & 0.488504 & 0.488504 & \begin{tabular}{|l|}
0.488504 \\
\end{tabular} \\
\hline DMU43 & & & & 0.266385 & 0.266385 & \begin{tabular}{|l|}
0.266385 \\
\end{tabular} \\
\hline DMU44 & & & & 0.148627 & 0.148627 & \begin{tabular}{|l|l|}
0.148627 \\
\end{tabular} \\
\hline DMU45 & & & & 0.544243 & 0.544243 & 0.544243 \\
\hline DMU46 & & & & 0.126275 & 0.126275 & 0.126275 \\
\hline DMU47 & & & & 0.307956 & 0.307956 & 0.307956 \\
\hline DMU48 & & & & 0.133064 & 0.133064 & 0.133064 \\
\hline DMU49 & & & & 0.215982 & 0.215982 & 0.215982 \\
\hline DMU50 & & & & 0.327164 & 0.327164 & 0.327164 \\
\hline DMU51 & & & & 0.340419 & 0.340419 & 0.340419 \\
\hline DMU52 & & & & 1.000000 & 1.000000 & 1.000000 \\
\hline DMU53 & & & & 0.732659 & 0.732659 & \begin{tabular}{|l|}
0.732659 \\
\end{tabular} \\
\hline DMU54 & & & & 0.522205 & 0.522205 & \begin{tabular}{|l|}
0.522205 \\
\end{tabular} \\
\hline DMU55 & & & & 0.422567 & 0.422567 & \begin{tabular}{|l|}
0.422567 \\
\end{tabular} \\
\hline DMU56 & & & & 0.387019 & 0.387019 & 0.387019 \\
\hline DMU57 & & & & 0.022979 & 0.022979 & 0.022979 \\
\hline DMU58 & & & & 0.041560 & 0.041560 & 0.041560 \\
\hline DMU59 & & & & & 0.477291 & 0.477291 \\
\hline DMU60 & & & & & 0.321932 & 0.321932 \\
\hline DMU61 & & & & & 0.178442 & 0.178442 \\
\hline DMU62 & & & & & 0.186759 & 0.186759 \\
\hline DMU63 & & & & & 0.074945 & 0.074945 \\
\hline DMU64 & & & & & 0.020127 & \begin{tabular}{|l|}
0.020127 \\
\end{tabular} \\
\hline
\end{tabular}




\begin{tabular}{|l|l|l|l|l|}
\hline DMU65 & & & 0.278792 & 0.278792 \\
\cline { 1 - 3 } & & & 0.443437 & 0.443437 \\
\hline
\end{tabular}

DMU67

DMU68

DMU69

DMU70

DMU71

DMU72

DMU73

According to Table 4 , in the $1^{\text {st }}, 2^{\text {nd }}$ and $3^{\text {rd }}$ iteration the units DMU7 and 12 are efficient. The fourth iteration is "decisive", as in further $4^{\text {th }}, 5^{\text {th }}$ and $6^{\text {th }}$ iterations, the efficient units include DMU12, 41 and 52.

The comparative results of the research of the Variants $A$ and $B$ of the Multiset DEA analysis indicate the units which should be further improved (highlighted), and the unit which remains efficient (bold), Table 5. This further indicates the relativity of efficiency, as practices are best, some in supersets, some however in basic sets.

Considering the efficient units from the monoset viewpoint, set BS1 should be partially improved, i.e. just one efficient unit (DMU7), sets BS2, BS3, BS5 and BS6 should completely improve their efficient units, while set BS4 "strong" is a set with both multiefficient units.

Unit DMU7 is multiinefficient due to the fact that it has been discovered as potentially inefficient within the multiset of fourth iteration and further to the superset. Based on this, target activities resulting from the Sensitivity analysis are proposed based on deceasing the input and/or increasing the output. Opposite to this, DMU12 unit is a multiset efficient unit, as it still remains as efficient as in the first set after the increase of the analysed set.

As the Passenger Transport Sector does not include the decision making units by which the analysed set would be enlarged, it is possible to add hypothetical units with hypothetical data in future observations and thus establish the complete ranking. In such future iterations, with new hypothetical units, it is necessary to further decrease the investment and/or increase the result for achieving efficiency. 
Table 5 - Result of the Multiset DEA analysis (Variant A, Variant B)

Таблица 5 - Результат мульти-множественного АОД анализа (Вариант A, Вариант Б)

Табела 5 - Резултат мултискуповне ДЕА анализе (варијанта А, варијанта Б)

\begin{tabular}{|c|c|c|c|c|c|}
\hline \multicolumn{2}{|c|}{ Variant A } & \multicolumn{4}{|l|}{ Variant B } \\
\hline $\begin{array}{l}\text { Basic } \\
\text { set }\end{array}$ & Efficient & $\begin{array}{l}\text { Basic set and aggregate basic } \\
\text { sets }\end{array}$ & Efficient & $\begin{array}{l}\text { Multi- } \\
\text { efficient }\end{array}$ & $\begin{array}{l}\text { Multi } \\
\text { inefficie } \\
\text { nt }\end{array}$ \\
\hline BS1 & $\begin{array}{l}\text { DMU7 } \\
\text { DMU12 }\end{array}$ & BS1 & $\begin{array}{l}\text { DMU7 } \\
\text { DMU12 }\end{array}$ & DMU12 & DMU7 \\
\hline BS2 & $\begin{array}{l}\text { DMU18 } \\
\text { DMU24 } \\
\text { DMU25 }\end{array}$ & $\mathrm{BS} 1+\mathrm{BS} 2$ & $\begin{array}{l}\text { DMU7 } \\
\text { DMU12 }\end{array}$ & DMU12 & DMU7 \\
\hline BS3 & $\begin{array}{l}\text { DMU30 } \\
\text { DMU37 }\end{array}$ & $\mathrm{BS} 1+\mathrm{BS} 2+\mathrm{BS} 3$ & $\begin{array}{l}\text { DMU7 } \\
\text { DMU12 }\end{array}$ & DMU12 & DMU7 \\
\hline BS4 & $\begin{array}{l}\text { DMU41 } \\
\text { DMU52 }\end{array}$ & $\mathrm{BS} 1+\mathrm{BS} 2+\mathrm{BS} 3+\mathrm{BS} 4$ & $\begin{array}{l}\text { DMU12 } \\
\text { DMU41 } \\
\text { DMU52 }\end{array}$ & DMU12 & - \\
\hline BS5 & $\begin{array}{l}\text { DMU59 } \\
\text { DMU66 }\end{array}$ & $\mathrm{BS} 1+\mathrm{BS} 2+\mathrm{BS} 3+\mathrm{BS} 4+\mathrm{BS} 5$ & $\begin{array}{l}\text { DMU12 } \\
\text { DMU41 } \\
\text { DMU52 }\end{array}$ & DMU12 & - \\
\hline BS6 & DMU67 & $\mathrm{BS} 1+\mathrm{BS} 2+\mathrm{BS} 3+\mathrm{BS} 4+\mathrm{BS} 5+\mathrm{BS} 6$ & $\begin{array}{l}\text { DMU12 } \\
\text { DMU41 } \\
\text { DMU52 }\end{array}$ & DMU12 & - \\
\hline
\end{tabular}

In conclusion, based on the numerical example, the following three definitions are provided:

- Definition 1: When a DMU is analysed in relation to other units in a bigger set, the DMU efficiency numerical value is smaller or equal to the efficiency obtained when a DMU is analysed in relation to other units in a smaller set. The estimation by the Multiset DEA analysis in a wider set is more restrictive than the evaluation by the monoset approach: Eff ${ }^{\text {multiset }} \leq$ Eff ${ }^{\text {set }}$.

- Definition 2: When a DMU is analysed in relation to other units in an aggregate set, the number of efficient units is smaller than the total number of efficient units when units are analysed in relation to other units within the basic set:

$$
\mathrm{N}_{\text {EffDMU }}{ }^{\text {multiset }} \leq \Sigma \mathrm{N}_{\text {EffDMU }}{ }^{\text {set }} \text {. }
$$


- Definition 3: Multiset efficient unit is efficient in both a basic set and a superset: Eff $_{\text {MSEff }}=1(B S, S S)$.

Additional clarification of efficiency, apart from the numerical value of efficiency, also includes the number of decision making units of the analysed set. It is a kind of weighted efficiency according to which efficient units are different and therefore comparable.

\section{Conclusion}

After reading the papers of the first and subsequent authors on the subject of the DEA method, it can be learnt that efficiency is a relative feature, as it varies depending on the data analysed. Additionally, the fact that this change may not only be positive (from inefficient to efficient unit), but also a negative one (from efficient to inefficient) has been ignored. Hence, the result of efficiency is only an estimate, and not an evaluation, that is, a final approximate value of efficiency.

With such more profound knowledge in mind, the objective of this paper is to acknowledge potentially inefficient units in order to avoid the previously stated negative process (efficient - inefficient), and sustain efficiency in such a way. In this regard, the Multiset DEA analysis has been proposed, which has also been explained from the theoretical point of view and practically illustrated, while in the end the research results were presented.

Theoretically, the Multiset DEA analysis is a mathematical way of calculating the efficiency of business operations of entities from different areas. The efficiency evaluations obtained by the Multiset analysis are re-evaluated, whereby new estimations of efficiency are equal or smaller than the previous ones, which implies very important information on potentially inefficient units.

Practically, the Multiset DEA analysis is illustrated at an actual example of Serbian railway passenger stations, which are an important part of both the railway segment and the environment. As a part of the changing environment, military sector is a more or less significant customer of transport services. We would like to mention in our paper the best practice units, Pančevački Most (DMU7) and Požarevac (DMU12) stations, within the Passenger Transport Section Belgrade, as well as Požarevac, Novi Sad and Indjija within the Passenger Transport Sector. The stated stations are: (i) an actually achievable model for inefficient units, (ii) a "live" proof of potential efficiency, and (iii) a confirmation of the application of the DEA method. The Požarevac station is a multiset 
efficient station, as it is efficient in the Sector, while DMU7 is potentially inefficient as it becomes inefficient in the Sector.

Based on the results, with certain units we expect a negative process (efficient $\rightarrow$ multineffecinet). Now that we know what awaits us, our future research will definitively be the Sensitivity analysis. This is the logical order (or a post DEA analysis) as it provides concrete target values of input-output parameters (smaller inputs and/or higher outputs), which is necessary to realise in practice so that multiinefficient units can become multiefficient. Targeted activities are different in each iteration and every time, and in any larger set. There is no doubt that with them in the future, efficient units of the basic set become stable, and they remain as efficient in the end as in the beginning. Therefore, the actual efficiency indicator is not only a pure numerical value, but also the number of units included in the analysis, which makes efficiency additionally defined. The extension of the case would include new inputs and outputs as characteristics of other subsystems, i.e. an analysis of the so-called DAT approach using sets and systems.

Additionally, future research refers to providing measures which encourage activities, and then measures possible to apply in concrete conditions. Now we will make a general proposal for better conversion input/output:

- New rational technology for the operation of stations (rational number of station personnel, rational redistribution of work, modernisation of operations, etc.);

- New rational organisation of railway transport (rational number of shares i.e. fewer trains, more departures, fewer "empty" lines, shorter stays and turning and line stations, which is to be achieved by a quality made timetables, etc.);

- Improved quality of transport service (timely departures, regular trains, comfort, providing information to passengers, travel without changing trains, accessibility of stations, diverse fee-related benefits etc.).

According to the presented system and the analogy to the case shown, the efficiency of entities from other activities may also be calculated, with completely different types of data (apart from the applied traffic-transport and demographic, economic and other statistical data). In the spirit of this magazine, we will mention organisational units, institutions and individuals of the Serbian Army, which is, similarly to the railway, a significant and complex, and above all, extremely important organisational system. 
Through constant innovation lasting for a number of decades, the DEA model of mathematical programming has become a subject of significant and important number of works which present the modified models and contemporary examples. In terms of such tendency, the presented subject of DEA is not a completely closed issue, but it instead eagerly waits for new ideas and new examples, all with a wider comprehension of the notion of efficiency.

\section{References}

Andersen, P. \& Petersen, N.C. 1993. A Procedure for Ranking Efficient Units in Data Envelopment Analysis. Management Science, 39(10), pp.12611264. Available at: https://doi.org/10.1287/mnsc.39.10.1261.

Banker, R.D., Charnes, A. \& Cooper W.W. 1984. Some models for estimating technical and scale inefficiencies in data envelopment analysis. Management Science, 30(9), pp.1078-1092. Available at: https://doi.org/10.1287/mnsc.30.9.1078.

Charnes, A., Cooper, W.W. \& Rhodes, E. 1978. Measuring the efficiency of decision making unit. European Journal of Operational Research, 2(6), pp.429444. Available at: https://doi.org/10.1016/0377-2217(78)90138-8.

Chen, K. \& Zhu, J. 2017. Second order cone programming approach to two-stage network data envelopment analysis. European Journal of Operational research, 262, pp.231-238. Available at: https://doi.org/10.1016/j.ejor.2017.03.074.

Diamond, S. 2015. Dobiti više - Kako da pregovaranjem postignete svoje ciljeve u stvarnom svetu. Belgrade: Samizdat B92 (in Serbian).

Lin, T.Y., Liu, C.M. \& Yeh, S.P. 2017. Evaluating the leisure benefits of ecoturism with data envelopment analysis. Applied ecology and environmental research, 15(2), pp.33-41. Available at: https://doi.org/10.15666/aeer/1502_033041.

Lukovac, V.M., Pejčić Tarle, S.A., Popović, M.J. \& Pamučar, D.S. 2014. Distribucijske greške u procesu procjene performansi zaposlenih. Vojnotehnički glasnik / MilitaryTechnical Courier, 62(4), pp.141-154 (in Serbian). Available at: https://doi.org/10.5937/vojtehg62-4729.

Ozcan, Y.A. \& Khushalani, J. 2017. Assessing efficiency of public health and medical care provision in OECD countries after a decade of reform. Central European Journal of Operations Research, 25(2), pp.325-343. Available at: https://doi.org/10.1007/s10100-016-0440-0.

Pamučar, D.S., Božanić, D.I. \& Kurtov, D.V. 2016. Fuzzification of the Saaty's scale and a presentation of the hybrid fuzzy AHP-TOPSIS model: An example of the selection of a brigade artillery group firing position in a defensive operation. Vojnotehnički glasnik / Military Technical Courier, 64(4), pp.966-986. Available at: https://doi.org/10.5937/vojtehg64-9262. 
Peixoto, M.G.M., Mendonça, M.C.A., Musetti, M.A., Batalha, M.O. \& Sproesser, R.L. 2017. Grain intermodal terminals: evaluation of pure technical efficiency by Data Envelopment Analysis. Production, 27, pp.1-13. Available at: https://doi.org/10.1590/0103-6513.205416.

Petrović Đorđević, D. 2015. Modeliranje, analiza i merenje efikasnosti sportskih organizacionih jedinica primenom DEA metode. University of Belgrade: Faculty of Organizational Sciences. Ph.D. thesis (in Serbian).

Rakić, Lj. 2017. Skup SANU: Mentalni poremećaji u samom vrhu uzroka narušenog kvaliteta života. [Internet]. Available at: http://www.rts.rs/page/stories/ci/story/124/drustvo/2938098/skup-sanu (in Serbian). Accessed: 15 November 2017.

Sagarra, M., Mar-Molinero, C. \& Agasisti, T. 2017. Exploring the efficiency of Mexican universities: Integrating data Envelopment Analysis and Multidimensional Scaling. Omega, 67(3), pp.123-133. Available at: https://doi.org/10.1016/j.omega.2016.04.006.

Savić, G. Merenje performansi poslovnih sistema. [Internet]. Available at: http://laboi.fon.bg.ac.rs/wpontent/uploads/dataPA/MEPS/Analizapromena.pdf.

Accessed: 1 November 2017 (in Serbian).

Si, L.-B. \& Qiao, H.-Y. 2017. Performance of Financial Expenditure in China's basic science and math education: Panel Data Analysis Based on CCR Model and BCC Model. Journal of Mathematics Science and Technology Education, 13(8), pp.5217-5224. Available at: https://doi.org/10.12973/eurasia.2017.00995a.

Stiglitz, J. 2008. Ekonomija javnog sektora. University of Belgrade: Faculty of Economics (in Serbian).

Takundwa, R., Jowett, S., McLeod, H. \& Peñaloza-Ramos M.C. 2017. The Effects of Environmental Factors on the Efficiency of Clinical Commissioning Groups in England: A Data Envelopment Analysis. Journal of Medical systems, 41(6), pp.1-7. Available at: https://doi.org/10.1007/s10916-017-0740-5.

Tran, K.D., Bhaskar, A., Bunker, J. \& Lee, B. 2017. Data Envelopment Analysis (DEA) based transit routes performance evaluation. In: TRB 2017: Transportation Research Board 96 ${ }^{\text {th }}$ Annual Meeting, Washington, pp.1-24. January 8-12. Available at: https://eprints.qut.edu.au/102900/TRB_2017_DEA\%20for\%\%20bus\%20routes_ Revised.pdf. Accessed: 1 November 2017.

Vamitha, V. \& Rajaram, S. 2015. A multiset based forecasting model for fuzzy time series. Hacettepe Journal of Mathematics and Statistics, 44(4), pp.965-973. Available at: http://www.hjms.hacettepe.edu.tr/uploads/0a84a462ce74-4813-ae7c-a189b1aa9ad9.pdf. Accessed: 1 November 2017.

Vešović, V., Bojović, N. \& Knežević, N. 2007. Organizacija saobraćajnih preduzeća. University of Belgrade: Faculty of Transport and Traffic Engineering (in Serbian).

Vuković, D.R. 2016. Railway Stations as Efficiency Decision-Making Units: Input and Output DEA Model. Tehnika, 71(3), pp.441-448. Available at: https://doi.org/10.5937/tehnika1603441V. 
Yang, Y., Ma, B. \& Koike, M. 2000. Efficiency-measuring DEA model for production system with $\mathrm{k}$ independent subsystem. Journal of the Operations Research Society of Japan, 43(3), pp.343-354. Available at: https://doi.org/10.15807/jorsj.43.343.

Welleck, S., Mao, J., Cho, K. \& Zhang, Z. 2017. Saliency-based Sequential Image attention with Multiset Prediction. In: NIPS 2017: 31 st Conference on Neural Information Processing Systems, Long Beach, CA, USA, pp.1-11. December 4-9. Available at: http://papers.nips.cc/paper/7102-saliency-basedsequential-image-attention-with-multiset-prediction.pdf. Accessed: 1 November 2017.

Živković, M.Z. \& Banjac, G.M., 2016. Energetski potencijali vojnih objekata. Vojnotehnički glasnik / MilitaryTechnical Courier, 64(1), pp.196-212 (in Serbian). Available at: https://doi.org/10.5937/vojtehg64-8165.

-Železnice Srbije. 2010. Sistematizacija radnih mesta. Belgrade: Internal file (in Serbian).

-Železnice Srbije. 2013. Red vožnje 2013/14. Belgrade: Želnid (in Serbian). -Železnice Srbije. 2014. Statistika 2013. Belgrade: Bajka 87 (in Serbian).

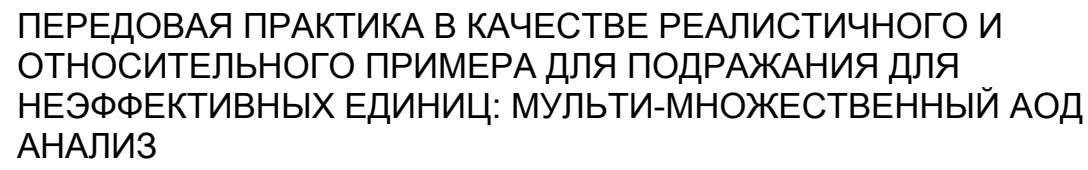

Дубравка Р. Вукович

«Сербия карго» AO, Транспортный сектор, г. Белград, Республика Сербия

ОБЛАСТЬ: математика, логистика, пути сообщения

ВИД СТАТЬИ: оригинальная научная статья

ЯЗЫК СТАТЬИ: английский

Резюме:

Исследования эфрфективности единиц принятия решения 8 настоящей работе проводились в следующем направлении: эфрфективная $\rightarrow$ мульти-неэффрективная $\rightarrow$ мульти-эфффективная единица. Следовательно, цель настоящей работы предусмотреть несколько шагов заранее, таких как: (1) идентификация "скрытых" неэффрективных единиц в мультимножестве, среди эффрективных единиц в основном множестве, (2) осуществление эффрективности в случаях идентифицированных неэфффективных единиц. Таким образом указывается (предупреждается!) на отрицательный процесс эффрективная $\rightarrow$ неэффрективная, и создается возможность для своевременного реагирования, в том числе и для предупреждения мульти-неэффрективности. Конкретной целью настоящей работы является оценка эффрективности сербских вокзалов и железнодорожных пассажирских станций, прежде всего в основном 
множестве Секции пассажирского транспорта Белград, а затем в мульти-множестве Секции пассажирского транспорта, и в конце в надмножестве - Секторе пассажирского транспорта. Это осуществляется с помощью применения мульти-множественного АОД метода (Анализ охвата данных), который представляет собой систему: (u) оценки относительной эфрфективности, в первой итерации, путем анализа основного множества, (ии) снижения эфрфективности потенциально неэфрфективных единии, в последующих итерациях, путем анализа мульти-множества. В результате - эфрфективные станции Пожареваи и Панчевачки мост находятся на начальном уровне, а (ново)эфрфрективные Пожаревац, Нови Сад и Инджия, на последнем уровне. Станция Пожаревац на практике остается лучшей станцией, и по своей мульти-эфрфективности является примером для подражания неэфрфективным единицам. Можно сделать вывод, что решение мульти-множественного АОД анализа в большей степени реалистично и в меньшей степени относительно, поскольку применимо к более широкому анализируемому множеству единии принятия решения, то есть к большему охвату рассмотрения проблемы. Данные показатели являются весьма значимыми, особенно, если учитывать тенденции возрастающей глобализации, в данной связи мы рекомендуем интегральный мульти-множественный подход, в отличии от индивидуального единично-множественного подхода.

Ключевые слова: эфрфективность, анализ среды функционирования, мульти-множественный анализ, железнодорожные станции.

НАЈБОЉА ПРАКСА КАО РЕАЛАН И РЕЛАТИВАН УЗОР

НЕЕФИКАСНИМ ЈЕДИНИЦАМА: МУЛТИСКУПОВНА ДЕА АНАЛИЗА

Дубравка Р. Вуковић

„Србија карго” АД, Сектор за саобраћајно-транспортне послове,

Београд, Република Србија

ОБЛАСТ: математика, логистика, саобраћај

ВРСТА ЧЛАНКА: оригинални научни чланак

ЈЕЗИК ЧЛАНКА: енглескИ

Сажетак:

Правац истраживања ефикасности јединица одлучивања у овом раду јесте ефрикасна $\rightarrow$ мултинеефикасна $\rightarrow$ мултиефикасна јединица, а опити циљ су два корака напред: (1) откривање "скривених" неефикасних јединица у мултискупу, међу ефикасним јединицама у основном скупу и (2) постизање ефикасности код 
откривених неефикасних јединица. Тиме се указује (упозорава!) на негативан процес ефикасна $\rightarrow$ неефикасна, како би се правовремено реаговало и тиме предупредила мултинеефикасност. Конкретни циљ јесте да се процени ефикасност железничких путничких станица у Србији, најпре у основном скупу Секције за превоз путника Београд, затим у мултискупу Секција за превоз путника и, на крају, у надскупу Сектор за превоз путника. То се постиже мултискуповном методом ДЕА (Data Envelopment Analysis), umo je систем за: (u) процењивање релативне ефикасности, у првој итерацији, анализом основног скупа, (ии) смањење ефикасности потенцијално неефикасних јединица, у наредним итерацијама, анализом мултискупа. Резултат је да су ефикасне станице Пожаревац и Панчевачки мост на почетном нивоу, а (ново)ефикасне Пожаревац, Нови Сад и Инђија на крајњем нивоу. Најбоља пракса је у станици Пожаревац, која је мултиефикасна и представља узор неефикасним јединицама. Закључује се да је решење мултискуповне ДЕА анализе више реално, а мање релативно, јер важи за шири анализирани скуп јединица одлучивања, mј. већи обухват сагледавања проблема. То је значајно за уклапање у ново доба растуће глобализације, те је наша препорука целовит мултискуповни приступ насупрот појединачном моноскуповном приступу.

Кључне речи: ефрикасност, Data Envelopment Analysis, мултискуповна анализа, железничке станице.

Paper received on / Дата получения работы / Датум пријема чланка: 27.12.2017.

Manuscript corrections submitted on / Дата получения исправленной версии работы / Датум достављања исправки рукописа: 22.02.2018.

Paper accepted for publishing on / Дата окончательного согласования работы / Датум коначног прихватања чланка за објављивање: 24.02.2018.

(c) 2018 The Author. Published by Vojnotehnički glasnik / Military Technical Courier (www.vtg.mod.gov.rs, втг.мо.упр.срб). This article is an open access article distributed under the terms and conditions of the Creative Commons Attribution license (http://creativecommons.org/licenses/by/3.0/rs/).

() 2018 Автор. Опубликовано в «Военно-технический вестник / Vojnotehnički glasnik / Military Technical Courier» (www.vtg.mod.gov.rs, втг.мо.упр.срб). Данная статья в открытом доступе и распространяется в соответствии с лицензией «Creative Commons» (http://creativecommons.org/licenses/by/3.0/rs/).

() 2018 Аутор. Објавио Војнотехнички гласник / Vojnotehnički glasnik / Military Technical Courier (www.vtg.mod.gov.rs, втг.мо.упр.срб). Ово је чланак отвореног приступа и дистрибуира се у складу са Creative Commons licencom (http://creativecommons.org/licenses/by/3.0/rs/).

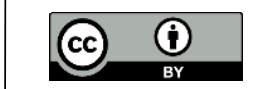

